\title{
ANALISIS FAKTOR YANG MEMPENGARUHI PEMBERIAN MAKANAN PENDAMPING ASI (MP-ASI) PADA BAYI (0-6 Bulan) DI DESA PADEMAWU BARAT KABUPATEN PAMEKASAN
}

\author{
Chairatul Izzaty, Puskesmas Pademawu Kabupaten Pamekasan \\ e-mail: izzalimited@gmail.com
}

\begin{abstract}
ABSTRAK
Makanan dan minuman bergizi yang diberikan pada anak usia 6-24 bulan dalam mencukupi kebutuhan gizinya adalah Makanan pendamping ASI (MP-ASI). Ibu memberikan MP-ASI sebelum usia 6 bulan karena ibu menganggap bayi tidak akan tumbuh dan berkembang secara optimal jika hanya diberikan ASI.

Desain penelitian ini adalah deskriptif dengan populasi semua ibu yang mempunyai anak usia 0-6 bulan berjumlah 50 orang. Sampel penelitian yaitu sebagian ibu yang mempunyai anak usia 0-6 bulan sebanyak 41 orang dengan teknik Simple Random Sampling.

Hasil penelititan yang diperoleh diketahui bahwa hampir setengahnya (46\%) persepsi responden dalam pemberian makanan pendamping ASI kurang, pengetahuan responden sebagian besar (66\%) kurang, dan hampir setengahnya (49\%) pengalaman responden dalam pemberian makanan pendamping ASI kurang.

Berdasarkan hasil penelitian, maka dapat diambil kesimpulanbahwa persepsi, pengetahuan dan pengalaman dalam memberikan makanan pendamping ASI (MP-ASI) pada bayi sebagian besar kurang sehingga ibu perlu menambah pengetahuan dan lebih banyak mencari informasi pemberian (MP-ASI) pada bayi agar waktu pemberian benar dan tepat sehingga bayi dapat tumbuh dan berkembang dengan baik dan tidak terjadi dampak negatif pada bayi.
\end{abstract}

Kata Kunci: Makanan Pendamping Asi (MP-ASI), Bayi (0-6 Bulan)

\section{PENDAHULUAN}

Kelompok bayi usia $0-12$ bulan sangat menentukan kelangsungan hidup seseorang. Usia 0 sampai 24 bulan adalah masa pertumbuhan dan perkembangan yang pesat dan termasuk periode emas sehingga harus diberikan gizi yang sesuai. Namun jika asupan gizi tidak sesuai tidak sesuai dapat mengganggu tumbuh kembang. Gizi dalam makanan dan minuman yang diberikan pada anak berumur 6-24 bulan dapat memenuhi kebutuhan gizinya merupakan Makanan pendamping ASI (Depkes RI, 2010).

Pemberian MP-ASI dini dapat menyebabkan konstipasi, diare, muntah bahkan alergi. (Nadesul, 2013). Namun kenyataanya banyak ibu memberikan MP-ASI sebelum usia 6 bulan karena ibu menganggap bayi tidak akan tumbuh dan berkembang secara optimal jika hanya diberikan ASI. Alasan lainnya karena produksi ASI yang sedikit, kesibukan bekerja, bayi menangis dan sering rewel, membuat bayi tidur nyenyak karena merasa kenyang, pengalaman pemberian MP-ASI pada usia 6 bulan dan kondisit anak tetap sehat sampai sekarang.

Pencegahan kematian bayi dapat dilakukan dengan pemberian ASI eksklusif selama enam bulan. pencegahan kematian 1,3 juta anak dapat dilakukan dengan Pemberian ASI Ekskusif (Rahmadhani, 2014). sekitar 2.000.200 bayi berusia 0-6 bulan yang sudah diberikan ASI Eksklusif tanpa ada tambahan makanan pendamping berdasarkan survei Demografi dan Kesehatan Indonesia tahun 2014. Berdasarkan data dari Kabupaten/Kota diketahui bahwa bayi 0-6 bulan di Jawa Timur pada tahun 2013 sebanyak 525.674 dan yang mendapat ASI Eksklusif sebesar 68,48\% tanpa makanan atau minuman lain.

Berdasarkan data yang ada di Kabupaten Pamekasan pada tahun 2013 jumlah bayi usia 0-6 bulan yaitu 10.145, mendapatkan ASI Eksklusif sebesar 49,32\%, pada tahun 2014 jumlah bayi usia 0-6 bulan sebanyak 10.662 dan bayi yang mendapat ASI Eksklusif sebesar 52\% dari target $70 \%$. Capaian ini mengalami peningkatan dari tahun sebelumnya. Masih rendahnya capaian ASI 
Eksklusif dikarenakan masih tingginya budaya masyarakat untuk memberikan makanan tambahan sedini mungkin kepada bayi sebelum 6 bulan. Berdasarkan survei awal penelitian di dusun Mungsapada Desa Pademawu Barat Kabupaten Pamekasan jumlah bayi usia 0-6 bulan terdapat 50 bayi dan yang menggunakan ASI Eksklusif sebesar $20 \%, 80 \%$ ibu memberikan makanan pendamping ASI kepada bayinya sebelum bayi mereka berusia 6 bulan ke atas.

Ketika bayi memasuki usia 6 bulan keatas beberapa elemen nutrisi seperti karbohidrat, protein, vitamin dan mineral dalam tubuh bayi yang terkandung dalam ASI tidak lagi mencukupi. Oleh karena itu sejak usia 6 bulan nutrisi tambahan harus diberikan dengan tepat. Menurut Chairani (2013) faktor yang mempengaruhi ibu dalam pemberian makanan pendamping ASI yaitu, pengetahuan, persepsi, serta pengalaman. Hal ini disebabkan sistem imun pada bayi yang berusia kurang dari 6 bulan belum sempurna, sehingga pemberian MP-ASI dini sama saja dengan memasukkan berbagai jenis kuman penyakit. Agar makanan pendamping ASI diberikan dengan benar dan tepat maka perlu adanya penyampaian informasi kepada ibu-ibu dalam memberikan MP-ASI pada bayi.

\section{METODE PENELITIAN}

Desain penelitian ini adalah deskriptif dengan cara pengumpulan data survey yaitu dengan mengumpulkan informasi dari persepsi seseorang, pengetahuan, dan pengalaman. Dalam penelitian ini menganalisis tentang faktor yang mempengaruhi pemberian makanan pendamping ASI pada bayi usia (0-6 bulan) di Desa Pademawu Barat Kabupaten Pamekasan. Sampel dalam penelitian ini adalah sebagian ibu yang mempunyai anak usia 0-6 bulan di Desa Pademawu Barat Kabupaten Pamekasan yang berjumlah 41 orang. jenis instrumen Close Ended dengan variasi Dichotomy Question

\section{HASIL PENELITIAN}

\section{Data Umum}

\section{Karakteristik Responden Berdasarkan} Umur

Tabel 1.1 Distribusi Karakteristik Responden Berdasarkan Umur Ibu di Desa Pademawu Barat Kabupaten Pamekasan Tahun 2017

\begin{tabular}{cccc}
\hline No & Umur/Tahun & $\mathbf{N}$ & $\mathbf{\%}$ \\
\hline 1 & 15-20 Tahun & 8 & 20 \\
2 & 21-25 Tahun & 21 & 51 \\
3 & 26-30 Tahun & 12 & 29 \\
\hline & Jumlah & $\mathbf{4 1}$ & $\mathbf{1 0 0}$ \\
\hline
\end{tabular}

tabel 1.1 menunjukkan bahwasebagian besar (51\%) responden yang berusia 21-25 tahun dan sebagian kecil (20\%) responden yang berusia 15-20 tahun.

\subsection{Karakteristik Responden Berdasarkan Pendidikan}

Tabel 1.2 Distribusi Karakteristik Responden Berdasarkan Pendidikan di Desa Pademawu Barat Kabupaten Pamekasan Tahun 2017

\begin{tabular}{cccc}
\hline No & Pendidikan & N & \% \\
\hline 1 & Tidak Sekolah & 3 & 7 \\
2 & SD & 4 & 10 \\
3 & SMP & 8 & 20 \\
4 & SMA & 14 & 34 \\
5 & Perguruan Tinggi & 12 & 29 \\
\hline & Jumlah & $\mathbf{4 1}$ & $\mathbf{1 0 0}$ \\
\hline
\end{tabular}

tabel 1.2 menunjukkan bahwa hampir setengahnya $(34 \%)$ responden berpendidikan SMA dan sebagian kecil $(7 \%)$ responden Tidak sekolah.

\subsection{Karakteristik Responden Berdasarkan Pekerjaan}

Tabel 1.3 Distribusi Karakteristik Responden Berdasarkan Pekerjaan di Desa Pademawu BaratKabupaten Pamekasan Tahun 2017

\begin{tabular}{cccc}
\hline No & Pekerjaan & N & \% \\
\hline 1 & Ibu Rumah Tangga & 6 & 15 \\
2 & Buruh Tani & 17 & 41 \\
3 & Swasta & 5 & 12 \\
4 & Pegawai Negeri & 14 & 34 \\
\hline & Jumlah & $\mathbf{4 1}$ & $\mathbf{1 0 0}$ \\
\hline
\end{tabular}

Tabel 1.3 menunjukkan bahwa hampir setengahnya $(41 \%)$ responden sebagai Buruh Tani dan sebagian kecil (12\%) responden bekerja swasta.

\subsection{Karakteristik Responden Berdasarkan Perolehan Informasi}

Tabel 1.4 Distribusi Karakteristik Responden Berdasarkan Perolehan Informasi di Desa Pademawu Barat Kabupaten Pamekasan Tahun 2017 


\begin{tabular}{|c|c|c|c|}
\hline No & Perolehan Informasi & $\mathbf{N}$ & $\%$ \\
\hline 1 & Petugas Kesehatan & 18 & 44 \\
\hline 2 & Media Massa & 0 & 0 \\
\hline 3 & Media Elektronik & 4 & 10 \\
\hline 4 & Belum Pernah & 19 & 46 \\
\hline \multicolumn{2}{|r|}{ Jumlah } & 41 & 100 \\
\hline \multicolumn{4}{|c|}{$\begin{array}{l}\text { tabel } 1.4 \text { menunjukkan bahwa hampir } \\
\text { setengahya }(46 \%) \text { responden belum pernah } \\
\text { mendapatkan informasi dan tidak satupun } \\
(0 \%) \text { responden mendapatkan informasi dari } \\
\text { media massa. }\end{array}$} \\
\hline
\end{tabular}

\subsection{Distribusi Responden Berdasarkan Usia} Bayi

Tabel 1.4 Distribusi Karakteristik Berdasarkan Usia Bayi di Desa Pademawu Barat Kabupaten Pamekasan Tahun 2017

\begin{tabular}{|c|c|c|c|}
\hline No & Usia Bayi & $\mathbf{N}$ & $\%$ \\
\hline 1 & 0-2 Bulan & 14 & 34 \\
\hline 2 & 3-4 Bulan & 20 & 49 \\
\hline 3 & 5-6 Bulan & 8 & 20 \\
\hline \multicolumn{2}{|c|}{ Jumlah } & 41 & 100 \\
\hline \multicolumn{4}{|c|}{$\begin{array}{l}\text { tabel } 1.5 \text { menunjukkan bahwa hampir } \\
\text { setengahnya }(49 \%) \text { responden bayi usia } 3-4 \\
\text { bulan dan sebagian kecil (20\%) responden } \\
\text { bayi usia 5-6 bulan. }\end{array}$} \\
\hline
\end{tabular}

\section{DATA KHUSUS}

Tabel 2.1 Distribusi Karakteristik Responden Berdasarkan Persepsi Ibu Dalam Pemberian Makanan Pendamping ASI (MP-ASI) Pada Bayi di Desa Pademawu Barat Kabupaten Pamekasan Tahun 2017

\begin{tabular}{cccc}
\hline No & Persepsi Ibu & N & \% \\
\hline 1 & Baik & 17 & 42 \\
2 & Cukup & 5 & 12 \\
3 & Kurang & 19 & 46 \\
\hline & Jumlah & $\mathbf{4 1}$ & $\mathbf{1 0 0}$ \\
\hline
\end{tabular}

tabel 2.1 menunjukkan dari 41 responden yang diteliti, diperoleh hampir setengahnya (46\%) persepsi responden dalam pemberian makanan pendamping ASI kurang dan sebagian kecil (12\%) cukup.

Tabel 2.2 Distribusi Karakteristik Responden Berdasarkan Pengetahuan Ibu Dalam Pemberian Makanan Pendamping ASI (MPASI) Pada Bayi di Desa Pademawu Barat Kabupaten Pamekasan Tahun 2017

\begin{tabular}{cccc}
\hline No & Pengetahuan Ibu & N & \% \\
\hline 1 & Baik & 5 & 12 \\
2 & Cukup & 9 & 22 \\
3 & Kurang & 27 & 66 \\
\hline & Jumlah & $\mathbf{4 1}$ & $\mathbf{1 0 0}$ \\
\hline
\end{tabular}

Berdasarkan tabel 2.2 menunjukkan bahwa dari 41 responden yang diteliti, diperoleh sebagian besar (66\%) pengetahuan responden dalam pemberian makanan pendamping ASI kurang dan sebagian kecil (12\%) baik.

Tabel 2.3 Distribusi Karakteristik Responden Berdasarkan Pengalaman Ibu Dalam Pemberian Makanan Pendamping ASI (MPASI) Pada Bayi di Desa Pademawu Barat Kabupaten Pamekasan Tahun 2017

\begin{tabular}{cccc}
\hline No & Pengalaman Ibu & N & \% \\
\hline 1 & Baik & 17 & 41 \\
2 & Cukup & 4 & 10 \\
3 & Kurang & 20 & 49 \\
\hline & Jumlah & $\mathbf{4 1}$ & $\mathbf{1 0 0}$ \\
\hline
\end{tabular}

Berdasarkan tabel 2.3 menunjukkan bahwa dari 41 responden yang diteliti, diperoleh hampir setengahnya $(49 \%)$ pengalaman responden dalam pemberian makanan pendamping ASI kurang dan sebagian kecil (10\%) cukup.

\section{PEMBAHASAN}

\section{Persepsi Ibu dalam Pemberian MP - ASI}

Berdasarkan hasil penelitian di dapatkan bahwa hampir setengahnya persepsi ibu dalam pemberian makanan pendamping ASI (MP-ASI) kurang, sedangkan sebagian kecil memiliki persepsi cukup baik dalam pemberian MP-ASI.Menurut James P. Chaplin (2012) persepsi adalah proses untuk mengetahui atau mengenal objek atau kejadian objektif yag menggunakan indra dan kesadaran dari proses - proses organis. persepsi merupakan kelompok penginderaan dengan penambahan arti - arti dari pengalaman yang lalu. Variabel yang menghalangi atau ikut campur tangan yang berasal dari kemampuan organisme untuk melakukan perbedaan di antara perangsang perangsang (Titchener, 2010)

Hasil penelitian yang dilakukan oleh Yulianto bahwa sebagian besar responden mempunyai persepsi yang negatif tentang Makanan Pendamping ASI sebanyak 20 
responden $(54,1 \%)$. Di Dusun Mungsapada Ibu memiliki persepsi MP-ASI boleh diberikan pada bayi dibawah usia 6 bulan, yang terjadi karena mereka faktor tradisi. Pemberian MPASI secara dini dinilai penting karena orangorang yang disekitarnya memberikan pisang lumat tidak menimbulkan dampak apapun pada bayinya. Jadi meskipun ibu mempunyai pengetahuan yang baik tentang makanan pendamping ASI tetapi mereka masih tetap berusaha memberikan makanan pendamping ASI karena mereka mengikuti tradisi yang sudah berjalan dan mereka menganggap bahwa makanan pendamping ASI tidak akan memberikan dampak buruk jika diberikan pada anak dibawah 6 bulan.

\section{Pengetahuan Ibu dalam Pemberian MP - ASI}

Faktor yang juga berpengaruh dalam pemberian MP-ASI yaitu pengetahuan. Pengetahuan adalah hasil tahu yang didapatkan setelah seseorang melakukan penginderaan pada objek tertentu. Penginderaan melalui pancaindra manusia, yaitu indra pendengaran, penglihatan, rasa dan raba serta penciuman (Notoatmodjo, 2012). Pengetahuan ibu tentang MP ASI merupakan hasil dari tahu karena faktor penginderaan terhadap suatu obyek tertentu pada bahan makanan yang diperlukan dan beraneka ragam, mengandung zat tenaga, zat pembangun serta dibutuhkan tubuh (Hapsari, 2013).

Berdasarkan hasil penelitian Eko Heryanto proporsi responden dengan pengetahuan kurangyang bayinya sudahdiberi MP-ASI dini yaitu 16 responden ( 64\%), Pengetahuan sangat penting dalam pemberian makanan tambahan pada bayi agar tau waktu pemberian makanan secara benar. Di Dusun Mungsapada Ibu tidak mengetahui waktu dan jenis MP-ASI yang baik dan benar pada bayi. masalah kesehatan pada bayi dapat diakibatkan oleh Ketidaktahuan tentang akibat pemberian makanan pendamping ASI dini dan cara pemberiannya serta kebiasaan yang merugikan kesehatan.

Pengalaman Ibu dalam Pemberian MP - ASI Pengalaman termasuk faktor selanjutnya yang mempengaruhi ibu dalam pemberian makanan pendamping ASI (MP-ASI) pada bayi, dimana dalam penelitian ini didapatkan hampir setengahnya pengalaman ibu kurang dan sebagian kecil cukup berpengalaman dalam memberikan MP-ASI yang tepat pada bayi. Menurut Endarmoko (2013).

Hasil penelitian Yulianto sebagian besar responden memiliki latar belakang budaya keluarga yang negatif atau lingkungan serkitarnya mendukung pemberian MP-ASI yaitu 20 responden $(54,1 \%)$. Pengalaman dalam memberikan MP-ASI di bawah usia 6 bulan di dukung oleh keluarga yang sebelumnya sudah sering memberikan MPASI dibawah usia 6 bulan.Di Dusun Mungsapada pemberian MP-ASI pada bayi secara dini dilakukan karena adanya dorongan dari keluarga. Kuatnya anggapan keluarga dahulu memberikan MP-ASI meskipun dibawah usia 6 bulan dapat membuat anaknya tumbuh dan berkembang dengan baik sehingga menyarankan kepada ibu untuk memberikan MP-ASI pada bayi ketika masih berusia dibawah 6 bulan.

\section{Pendidikan Ibu dalam Pemberian MP - ASI}

Faktor yang berpengaruh pada MP-ASI selain persepsi, pengetahuan dan pengalaman juga di karenakan pendidikan, dalam penelitian ini didapatkan bahwa taraf pendidikan responden hampir setengahnyaberpendidikan SMA.

Hasil penelitian Baharuddin yaitu tingkat pendidikan sedang 7 responden (33.3\%), pendidikan tinggi sekali 7 responden $(33.3 \%)$, pendidikan tinggi 4 responden $(19.0 \%)$, dan pendidikan rendah 3 responden (14.3\%). Dengan melihat data ini dapat dikatakan bahwa taraf pendidikan secara umum mempengaruhi bentuk pemikiran dan tindakan yang dilakukan oleh ibu dalam memberikan MP - ASI.

\section{Pekerjaan Ibu dalam Pemberian MP - ASI}

Selain itu juga dapat dipengaruhi oleh faktor pekerjaan ibu, dimana pekerjaan ibu disini hampir setengahnya adalah buruh tani. Menurut Notoatmojo (2012) jenis pekerjaan yang dapat dikategorikan yaitu wiraswata, tidak bekerja, PNS, dalam semua bidang pekerjaan pada umumnya diperlukan adanya hubungan sosial yang baik dengan baik.

Penelitian Yonatan Kristianto didapatkan $52 \%$ ibu yang tidak bekerja memberikan MP-ASI terlalu dini dan $48 \%$ 
memberi makanan pendamping ASI tepat. Kondisi ini menghubungkan kenyataan bahwa ibu memberikan MP - ASI dibawah 6 bulan agar bayinya merasa kenyang dan tidak rewel saat ibu meninggalkan bayi untuk bekerja.

\section{Perolehan Informasi dalam Pemberian MP - ASI}

Faktor yang mempengaruhi dalam memberikan MP-ASI juga didukung dengan mengetahui seberapa sering dan dari mana responden memperoleh informasi. Hal ini dapat dibuktikan dengan tabel 5.4 yang menunjukkan perolehan informasi responden hampir setengahnya belum pernah mendapatkan informasi. Dengan melihat data ini dapat dikatakan bahwa responden kurang dalam memperoleh informasi mengenai MP ASI. Menurut Health (2009 dalam Linawati, 2013). informasi dari pendidikan formal dan non formal bisa mempengaruhi dalam peningkatan pengetahuan. Penelitian Hermina didapatkan hasil sebanyak $51,3 \%$ responden $(n=327)$ tidak pemah mendapat informasi dari tenaga kesehatan (nakes).

\section{KESIMPULAN}

Persepsi ibu hampir setengahnya kurang, pengetahuan ibu dalam pemberian MP-ASI sebagian besar kurang, dan pengalaman ibu dalam memberikan makanan pendamping ASI (MP-ASI) hampir setengahnya kurang.

\section{SARAN}

Berdasarkan penelitian yang dilakukan dan kesimpulan penelitian, maka didapatkan saransaran yang dapat berguna untuk pembaca. Saran tersebut diantaranya :

1. Bagi Profesi Keperawatan

Penelitian ini memerlukan adanya peningkatan sebagai fasilitator dan pendidik kesehatan masyarakat, sehingga dapat dijadikan sebagai bahan masukan bagi masyarakat khususnya bagi ibu untuk memberikan makanan pendamping ASI dengan benar dan tepat pada bayi.

2. Bagi Institusi Pendidikan

Penelitian ini memerlukan adanya upaya dari pihak terkait untuk lebih meningkatkan penyebarluasan informasi mengenai tugas kesehatan yang dapat dilakukan oleh ibu bagi keluarga dengan anak usia 0-6 bulan.
a. Bagi Peneliti Keperawatan Yang Akan Datang

Dalam hal ini peneliti selanjutnya dapat menggunakan penelitian ini sebagai acuan dasar untuk meneliti tentang faktor yang mempengaruhi (MP-ASI) pada bayi.

b. Bagi Responden (Ibu)

Dalam hal ini ibu perlu menambah pengetahuan dan lebih banyak mencari informasi dalam memberikan makanan pendamping ASI (MP-ASI) pada bayi.

\section{DAFTAR PUSTAKA}

Chairani.(2013). Faktor-faktor yang berhubungan dengan pemberian makanan pendamping ASI dini pada Bayi 6-12 Bulan. Jurnal Kesehatan. (hal 9-12)

Depkes RI.(2013). Buku Kesehatan Ibu dan Anak. Jakarta : Departemen Kesehatan

Depkes RI.(2013). Hubungan Pemberian Makanan Pendamping ASI (MPASI) pada Anak Usia 0-24 Bulan dengan Kejadian Diare. Skripsi Kesehatan Masyarakat. Universitas Muhammadiyah Surakarta. Surakarta

Donna, L.Wong.2013. Buku Ajar Keperawatan Pediatri Edisi 6. Jakarta:EGC

Endarmoko.(2013). Gambaran Pemberian MP-ASIPada Bayi Usia Kurang dari 6 Bulan. Skripsi Kesehatan Masyarakat. UIN Syahid. Jakarta

Hasdianah.(2015). Buku Ajar Dasar-Dasar Riset Keperawatan. Yogyakarta : Nuha Medikal

Husaini, Y.K.(2013). Makanan Bayi Bergizi. Yogyakarta : Gajah Mada University

Press.Irianto, Waluyo.(2013). Hubungan Pemberian Makanan Pendamping ASI (MP- ASI) pada Anak Usia 0-24 Bulan dengan Kejadian Diare. SkripsiKesehatan Masyarakat. Universitas Muhammadiyah Surakarta. Surakarta

Marzoeki.(2014). ). Faktor-faktor yang berhubungan dengan Pengetahuan Ibu dalam memberikan makanan pendamping Air Susu Ibu. Skripsi Keperawatan. UIN Syahid. Jakarta Mukhtar.(2013). Metode Praktis Penelitian Deskriptif Kualitatif. Jakarta:Referensi 
Notoatmodjo.(2012). Faktor-faktor yang berhubungan dengan Pengetahuan Ibu dalam memberikan makanan pendamping Air Susu Ibu. Skripsi Keperawatan. UIN Syahid. Jakarta

Pardosi.(2014). Gambaran Pemberian MPASIPada Bayi Usia Kurang dari 6 Bulan. Skripsi Kesehatan Masyarakat. UIN Syahid. Jakarta

Pieter, Herri Zan.(2010). Pengantar Psikologi dalam Keperawatan. Jakarta : Kencana

Sudijono.(2012). Gambaran Pemberian MPASIPada Bayi Usia Kurang dari 6 Bulan. Skripsi Kesehatan Masyarakat. UIN Syahid. Jakarta

Susila.(2014). Gambaran Pemberian MPASIPada Bayi Usia Kurang dari 6 Bulan. Skripsi Kesehatan Masyarakat. UIN Syahid. Jakarta 